\title{
Characterization of pectin depolymerising exo polygalacturonase by Bacillus sp. HD2 isolated from the gut of Apis mellifera L.
}

\author{
Yagya Prasad Paudel' ${ }^{1}$ Chaoyang Lin ${ }^{1,2}$, Zhicheng Shen² and Wensheng Qin ${ }^{1 *}$ \\ *Correspondence: wqin@lakeheadu.ca

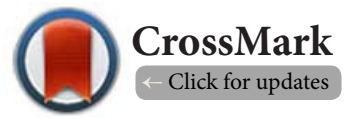 \\ 'Department of Biology, Lakehead University, 955 Oliver Road, Thunder Bay, Ontario, P7B 5E1, Canada. \\ ${ }^{2}$ State Key Laboratory of Rice Biology and Institute of Insect Science, College of Agriculture and Biotechnology, Zhejiang University, \\ 866 Yuhangtang Road, Hangzhou 310058, China.
}

\begin{abstract}
Background: Polygalacturonase is an important pectin degrading enzyme. The western honey bee (Apis mellifera L.) collects pollens from different flowers which are rich source of pectin. The microbiota in the gut of honey bee, release polygalacturonase enzyme and help in pectin digestion. This study aims to isolate and characterize novel polygalacturonase producing bacterial strain from honey bee's gut.

Methods: The bacterial strain was isolated by using pectin agar plate assay. The bacterial strain was identified on the basis of morphology and $16 \mathrm{~S}$ rDNA sequence analysis. The enzyme assay was performed by using pectin as a substrate. Biomass of different fruits/vegetables was also used as a source of carbon during fermentation. The protein gel was run using SDS-PAGE for molecular weight determination of the polygalacturonase.

Results: The bacterial strain showed the maximum growth, protein and polygalacturonase production at 72 hours of incubation. This bacterial strain was identified as new Bacillus sp. HD2. The sequence of this strain was successfully uploaded in NCBI Genbank database (Accession no. KP676929). The exo polygalacturonase produced by this strain of Bacillus was optimal at $40^{\circ} \mathrm{C}$ and exhibited enzyme activity in a wide range of $\mathrm{pH}$ from $\mathrm{pH} 5-12$. The polygalacturonase production was enhanced by using yeast extract $(3 \%)$ in the production medium and the enzyme activity was stimulated by $\mathrm{Ca}^{2+}(2 \mathrm{mM})$ and SDS $(200$ $\mathrm{mM}$ ). Biomass of apple's peel (1\%) was found as an excellent source of carbon for the polygalacturonase production in fermentation medium $\left(17.11 \pm 0.46 \mu \mathrm{mol} \mathrm{ml}^{-1} \mathrm{~min}^{-1}\right)$. In SDS-PAGE gel, the two clear bands of polygalacturonase were found at $\sim 36 \mathrm{kDa}$ and $\sim 72 \mathrm{kDa}$.

Conclusions: A new bacterial strain Bacillus sp. HD2 was isolated from the gut of honey bee. This strain produced the exo polygalacturonase enzyme. This enzyme was characterized under different $\mathrm{pH}$ and temperature and found to have maximum activity in $\mathrm{pH} 11$ at $40^{\circ} \mathrm{C}$. Apple peel's biomass was found as a good source of carbon during fermentation for polygalacturonase production. The SDS-PAGE analysis confirmed two bands of protein with polygalacturonase activity at $\sim 36 \mathrm{kDa}$ and $\sim 72 \mathrm{kDa}$.
\end{abstract}

Keywords: Pectin, polygalacturonase, isolation, Bacillus, biomass

\section{Introduction}

The natural diet of honey bee is mainly plant nectar and pollen. Pectin is an important polysaccharide which helps to form different layers in pollen wall [1]. The honey bee mid gut bacteria help to facilitate the digestion of pollen by releasing pectin degrading enzymes [2]. Engel et al., (2012) identified the genes which encode pectin degrading enzymes in bacteria of honey bee's gut [3]. Pectin digestion in honey bee gut might be helpful in resulting the release of nutrient from pollen. Also, the pectin has been shown to be toxic to honey bees [4], its digestion by gut bacteria might help the bees by avoiding intoxication. Pectin hydrolysing enzymes are known as pectinolytic enzymes or pectinases. There are three types of pectinases; pectin methyl esterase, pectin lyase and polygalacturonase. Pectin methyl esterase helps in the de-esterification of pectin by breaking ester bond between the methyl group and carboxylic acid of galacturonic residues. Pectin lyase breaks the glycosidic bonds between galacturonic 
Paudel et al. Microbiology Discovery 2015,

residues by trans-elimination reaction and polygalacturonase (PG) helps in the hydrolysis of a-1, 4 glycosidic bonds of pectin polymer converting into its galacturonic acid units [5]. Polygalacturonases have industrial importance since they help to decrease the viscosity, increase the fruit juice yield and help to determine the crystalline structure of fibers [6].

In the industrial sector, acidic pectinases are used in the extraction and clarification of fruit juices [7], whereas, alkaline pectinases have great commercial importance in the treatment of effluents discharged from fruit processing units [8], coffee and tea fermentation, oil extraction, processing and degumming of plant fibres such as ramie $[9,10]$. The alkaline pectinases have also been used in several biotechnological processes, like purification of plant viruses [11] and paper making [12]. The major source of acidic pectinases are fungi. The alkaline pectinases are produced from alkalophilic bacteria, mainly Bacillus spp. Although many fungi produce polygalacturonases [13], they are slow growing. The aim of this study was to isolate the bacterial strain capable of producing polygalacturonase from the gut of western honey bee (Apis mellifera L.) and optimization for maximum polygalacturonase production by the isolated strain.

\section{Material and methods}

\section{Growth media}

For the bacterial growth, the media used include pectin agar (pectin $5 \mathrm{gl}^{-1}, \mathrm{NaNO}_{3} \mathrm{lg} \mathrm{l} \mathrm{l}^{-1}, \mathrm{~K}_{2} \mathrm{HPO}_{4} 1 \mathrm{~g} \mathrm{l}^{-1}, \mathrm{KCl} 1 \mathrm{gl}^{-1}, \mathrm{MgSO}_{4} 0.5 \mathrm{gl}^{-1}$ yeast extract $0.5 \mathrm{~g} \mathrm{I}^{-1}$, agar $15 \mathrm{~g} \mathrm{I}^{-1}$ and LB (Luria-Bertani) liquid media $\left(10.0 \mathrm{~g} \mathrm{l}^{-1}\right.$ peptone, $5.0 \mathrm{~g} \mathrm{l}^{-1}$ yeast extract and $\left.5.0 \mathrm{~g} \mathrm{I}^{-1} \mathrm{NaCl}\right)$.

\section{Isolation of bacteria using pectin agar medium}

The bacterial strains were isolated from the gut of western honey bee (Apis mellifera L.). For the isolation of bacterial strains, the gut sample from a honey bee was suspended in $10 \mathrm{ml}$ of sterile potassium phosphate buffer solution (PBS). After vortexing the solution, a 10X serial dilution of the suspension was made in $1 \mathrm{X}$ PBS ( $\mathrm{pH} 7$ ). Thereafter, $100 \mu \mathrm{l}$ of each dilution in the series was spread onto the surface of pectin agar using the standard spread plate technique. The plates were incubated at $28^{\circ} \mathrm{C}$ for $24 \mathrm{~h}$. The bacterial colonies were selected based on their morphology (size and color) [14]. Pure cultures were repeatedly sub cultured on pectin agar plates and maintained for enzyme studies.

\section{Screening of isolates for polygalacturonase activity}

The isolates were screened for polygalacturonase activity by culturing it in the pectin agar medium. The clear zone around colony was detected while testing it with potassium-iodide solution [15]. The strain showing maximum zone of hydrolysis was selected for further assay.

\section{DNA isolation and 16S rDNA amplification}

The polygalacturonase producing isolate HD2 was grown in LB broth for $24 \mathrm{~h}$ at $28^{\circ} \mathrm{C}$. Genomic DNA was isolated using
Geneaid DNA extraction kit (Frogga Bio, Canada) by following the manufacturer's protocol. The DNA was amplified by using HAD-1 (5'-GACTCCTACGGGAGGCAGCAGT-3') and E1115R (5'-AGGGTTGCGCTCGTTGCGGG-3') primers. The PCR reaction mixture contained Taq buffer (10X), $\mathrm{MgCl}_{2}(25 \mathrm{mM})$, dNTPs (0.4 $\mathrm{mM})$, primers $(10 \mathrm{mM})$, Taq DNA polymerase $(0.25 \mathrm{U} / \mu \mathrm{l}), \mathrm{ddH} 2 \mathrm{O}$ $(7.5 \mu \mathrm{l})$ and DNA template $(3 \mu \mathrm{l})$. The PCR program used was as follows: primary denaturation 3 minutes at $95^{\circ} \mathrm{C}$, followed by 35 amplification cycles consisting of denaturing at $95^{\circ} \mathrm{C}$ for 1 minute, annealing for 1 minute at $63^{\circ} \mathrm{C}$, and extension at $72^{\circ} \mathrm{C}$ for 1 minute. Upon completion of 35 amplification cycles, a final extension step was done at $72^{\circ} \mathrm{C}$ for 10 minutes. The amplified DNA was visualized on $1 \%$ agarose gel to confirm size, quantity and purity. The PCR product was purified by using Geneaid PCR/Gel purification kit (Frogga Bio, Canada). Then the purified PCR products were sent for sequencing to Eurofins Genomics (U.S).

\section{Isolate identification}

BLAST (Basic Local Alignment Search Tool) program of NCBI database (http://blast.ncbi.nlm.nih.gov/) was used for identifying the possible genus of the isolate from the sequencing result.

\section{Polygalacturonase production media}

The polygalacturonase production was assayed using submerged fermentation technique in the Dubois salt medium $\left(\mathrm{NaNO}_{3}-0.1 \mathrm{gl}^{-1}, \mathrm{~K}_{2} \mathrm{HPO}_{4} 0.1 \mathrm{gl}^{-1}, \mathrm{KCl} 0.1 \mathrm{gl}^{-1}, \mathrm{MgSO}_{4} 7 \mathrm{H}_{2} \mathrm{O}-0.05\right.$ $\mathrm{gl}^{-1}$ ) containing $1 \%$ pectin (Acros Organics, Practical Grade, Fisher Scientific, Canada). For the biomass fermentation, 1\% biomass from different fruits/vegetables used as a source of carbon in Dubois salt medium.

\section{Enzyme assay and total protein determination}

The isolate HD2 was further screened for the quantitative polygalacturonase activity and total protein estimation by transferring $7 \mu$ l of an overnight culture to $7 \mathrm{~mL}$ of Dubois pectin media ( $\mathrm{pH} 7.0)$ in a glass culture tube. The cultures were incubated for up to five days. The enzyme in the culture medium was harvested in the $1^{\text {st }}, 2^{\text {nd }}, 3^{\text {rd }}, 4^{\text {th }}$ and $5^{\text {th }}$ days of incubation. The enzyme activity was determined by measuring the release of reducing groups using the Dinitrosalicylic acid reagent DNS assay [16] using pectin as substrate for polygalacturonase activity. For this, $10 \mu \mathrm{l}$ of enzyme supernatant was added to $90 \mu \mathrm{l}$ of substrate buffer $(0.5 \%$ pectin in $0.05 \mathrm{M}$ potassium phosphate buffer, $\mathrm{pH}$ 6-13) and incubated at $40-50^{\circ} \mathrm{C}$ for $15 \mathrm{~min}$. The reducing sugar released as galacturonic acid was determined. The cell free supernatant was used to evaluate the total protein by Bradford assay [17] using bovine serum album as standard.

Optimization of polygalacturonase production Effect of incubation time on polygalacturonase production Effect of incubation time was studied by incubating the bac- 
teria in production medium for different time intervals $(24 \mathrm{~h}$ $48 \mathrm{~h}, 72 \mathrm{~h}, 96 \mathrm{~h}$, and $120 \mathrm{~h}$ ). Also, the growth of bacteria was monitored by measuring the optical density (O.D) at $600 \mathrm{~nm}$ and the cell free supernatant was used for the enzyme assay. Effect of $\mathrm{pH}$ and temperature on polygalacturonase activity The impact of the $\mathrm{pH}$ on enzyme activity was determined by performing the assay at different $\mathrm{pH}$ levels from $\mathrm{pH} 5.0$ to 13.0 with cell free supernatant. For this, different $\mathrm{pH}$ buffers were used (Citrate buffer pH 5-6, PBS buffer pH 7-8, Glycine+ $\mathrm{NaOH}$ buffer $\mathrm{pH}$ 9-11 and $\mathrm{KCl}+\mathrm{NaOH}$ buffer $\mathrm{pH} 12-13)$. Similarly, the polygalacturonase activity was assessed at different temperatures ranging from $30^{\circ} \mathrm{C}$ to $70^{\circ} \mathrm{C}$.

\section{Effect of different nitrogen source on polygalacturonase production}

In order to study the impact of nitrogen source on enzyme production, bacterial culture was grown in fermentation medium containing various nitrogen sources $(0.5 \% \mathrm{w} / \mathrm{v})$. The different nitrogen sources were yeast extract, peptone, urea and ammonium sulphate. Similarly, the effect of concentration of yeast extract on polygalacturonase production by bacterial strain HD2 was studied by using different concentration of yeast extract ranging from 1 to $5 \%(\mathrm{w} / \mathrm{v})$ in the production medium.

\section{Effect of metal ions on polygalacturonase activity}

The effect of different metal ions $\mathrm{Ca}^{2+}, \mathrm{Co}^{2+}, \mathrm{Mg}^{2+}, \mathrm{Mn}^{2+}$ and $\mathrm{Zn}^{2+}$ in their chloride and sulphate salts on the activity of polygalacturonase was determined by performing the enzyme assay in the presence of these metal ions $(2 \mathrm{mM})$ at $40^{\circ} \mathrm{C}$ for $15 \mathrm{~min}$. For this assay, the reaction mixture contained $10 \mu \mathrm{l}$ enzyme supernatant, $10 \mu \mathrm{l}$ metal ion, $30 \mu \mathrm{l}$ buffer and $50 \mu \mathrm{l} 1 \%$ substrate (pectin). Further, the effect of different concentration of $\mathrm{Ca}^{2+}$ from $1 \mathrm{mM}$ to $5 \mathrm{mM}$, was determined by performing the polygalacturonase assay at $40^{\circ} \mathrm{C}$ for $15 \mathrm{~min}$.

\section{Effect of detergents on polygalacturonase activity}

The effects of detergents Sodium Dodecyl Sulphate (SDS, $10 \mathrm{mM}$ ) and Triton X-100 (10\%) were observed on the polygalacturonase activity. The assay conditions were same as that of metal ions except the detergents were used instead of metal ions. Also, different concentrations of SDS were used ranging from $50 \mathrm{mM}$ to $300 \mathrm{mM}$ to determine the effects of these concentrations on polygalacturonase activity.

\section{Effect of biomass on polygalacturonase production}

For the assay of polygalacturonase production in fermentation state, different fruit peels (apple, pomengrate and orange) and vegetables peels (potato and squash) were used. The fruit/ vegetables' peels were dried and powdered by a grinding machine. The overnight LB broth grown bacterial strain was inoculated in a powdery biomass $(1 \% \mathrm{w} / \mathrm{v})$ with Dubois salt medium for the fermentation and the polygalacturonase activity was determined at $72 \mathrm{~h}$ of incubation.

\section{SDS-Polyacrylamide gel electrophoresis (PAGE)}

The enzyme was confirmed by using SDS-PAGE. Ten percent SDS-PAGE was performed on the polygalacturonase by the method described by Laemmli [18]) using Bio-Rad electrophoresis apparatus. The protein marker and enzyme were allowed to run simultaneously to determine the molecular weight of the enzyme. After completion of the electrophoresis, coomassie brilliant blue R-250 was used to stain the gel. The gel containing $0.25 \%$ pectin was used for detection of PG activity. The gel was then washed with $2 \%$ Triton X-100 for 30 min, it was transferred in $\mathrm{pH} 11$ and then incubated at $40^{\circ} \mathrm{C}$ for $30 \mathrm{~min}$. After that the gel was stained with $0.1 \%$ Congo Red solution and the stained was removed with $1 \mathrm{M} \mathrm{NaCl}$ to visualize the clear bands of PG activity.

\section{Statistical analysis}

All the experiments were performed in triplicates and the results are expressed in terms of mean $\pm \mathrm{SD}$ (standard deviation). The statistical analysis of data was performed by one way Analysis of Variance (ANOVA) followed by Duncan's multiple comparison test $(p<0.05)$. Tests for normality by KolmogorovSmirnov test and Shapiro-Wilk test were performed to check if assumptions of ANOVA were met before the analysis.

\section{Results and discussion}

In this study, four bacterial strains were isolated from gut of western honey bee (Apis mellifera L.). For screening purpose, these bacteria were grown in pectin agar plate and pectinolytic activity was detected using plate assay. The isolate HD2 showed maximum pectinolytic activity on pectin agar plate. Sequencing results were successfully obtained for this isolate's $16 \mathrm{~S}$ rDNA PCR products. The DNA sequences were analysed by the nucleotide BLAST feature of the NCBI database to obtain possible identities based on homology. From the BLAST, the isolate was $99 \%$ similar to genus Bacillus. The sequence of this strain was successfully uploaded to NCBI Genbank database (Accession no. KP676929). This strain was further screened for exo polygalacturonase activity.

Bacterial growth, polygalacturonase production and the total protein determination

Bacterial growth is an important factor for the production of the enzymes. The growth factors are also of prime importance in industrial production for high production of enzymes for different applications. Bacteria show high levels of pectinases in pectin supplemented media [19]. The pattern of polygalacturonase production with reference to incubation period was monitored and the results showed that the Bacillus sp. HD2 showed considerable growth and maximum enzyme production $\left(12.44 \pm 0.8 \mu \mathrm{mol} \mathrm{ml}^{-1} \mathrm{~min}^{-1}\right)$ at $72 \mathrm{~h}$ of incubation (Figure 1) which was higher than other strains of Bacillus like B. sphaericus MTCC 7542 [20]. The production of polygalacturonase was decreased gradually $(p<0.05)$ after $72 \mathrm{~h}$ of incubation. Also, the total protein in the supernatant 
Paudel et al. Microbiology Discovery 2015,

was found maximum $(118.22 \pm 5.41 \mu / \mathrm{ml})$ at $72 \mathrm{~h}$ of incubation (Figure 2). The decrease in the growth, supernatant protein and enzyme activity after $72 \mathrm{~h}$ of incubation might be due to the loss of bacterial vitality which occurs after the limited growth.

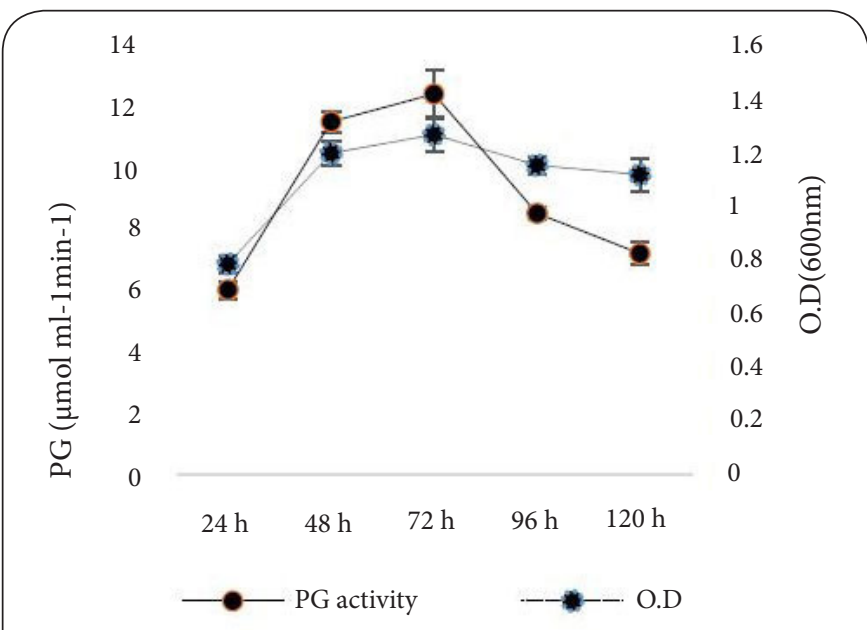

Figure 1. OD and PG activity at different time intervals.

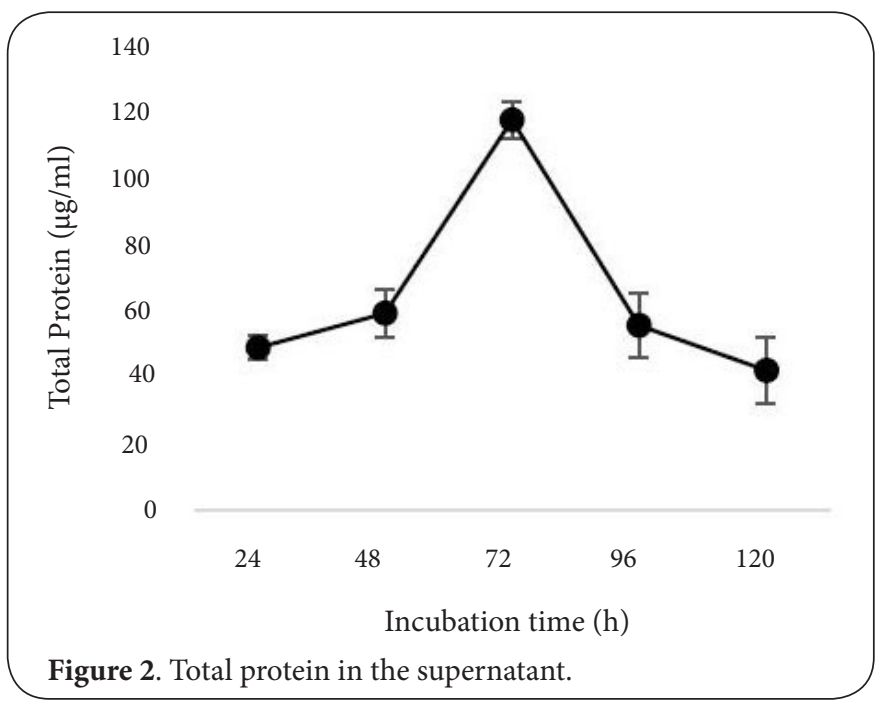

Effect of $\mathbf{p H}$ and temperature on enzyme activity

$\mathrm{pH}$ plays a significant role in the stability of enzyme activity. The present polygalacturonase from Bacillus strain was stable in the broad range of $\mathrm{pH}$. The maximum polygalacturonase activity was found at $\mathrm{pH} 11$ which was significantly different $(p<0.05)$ than other $\mathrm{pH}$ levels (acidic and neutral). The relative enzyme activity showed that the PG was also active even in acidic $\mathrm{pH}$ retaining its activity of $56 \%$ at $\mathrm{pH} 5$ (Figure $3 \mathrm{~A}$ ). Similar results of different alkaline polygalacturonase by different species of Bacillus were reported by other researchers [21-24]. Kapoor (2000) also reported that the polygalacturonase produced by Bacillus sp. MG-cp-2 was stable in alkaline conditions $\mathrm{pH}$ 7-12 [25]. Similarly, a polygalacturonase from Klebsiella sp.
$\mathrm{Y} 1$ was reported to be stable in a wide range of $\mathrm{pH}(2-12)$ in digestive tract of sheep [26].

Like $\mathrm{pH}$, temperature stability of enzyme is important for industrial application [27]. The effect of temperature on polygalacturonase production by strain $\mathrm{HD} 2$ was studied at different temperature ranging from $30^{\circ} \mathrm{C}$ to $70^{\circ} \mathrm{C}$. The enzyme was stable in a wide range of temperature and an increased polygalacturonase activity was found at $40^{\circ} \mathrm{C}$. The polygalacturonase activity was reduced significantly $(p<0.05))$ at the temperatures below $40^{\circ} \mathrm{C}$. The PG was stable even at $70^{\circ} \mathrm{C}$ retaining $66 \%$ of its enzyme activity (Figure 3B). A moderate temperature is important for longer incubation period to reduce the cost of enzyme production [21]. The results were similar with the temperature optimization for polygalacturonase from Bacillus subtilis DT7 [28].

\section{Effect of different nitrogen source $(0.5 \%)$}

Maximum polygalacturonase $(p<0.05)$ production was achieved when yeast extract (YE) was used in culture indicating $8 \%$ increment over the control treatment without any nitrogen source followed by peptone (Figure 4A). It might be because of the fact that yeast extract has essential vitamins, minerals

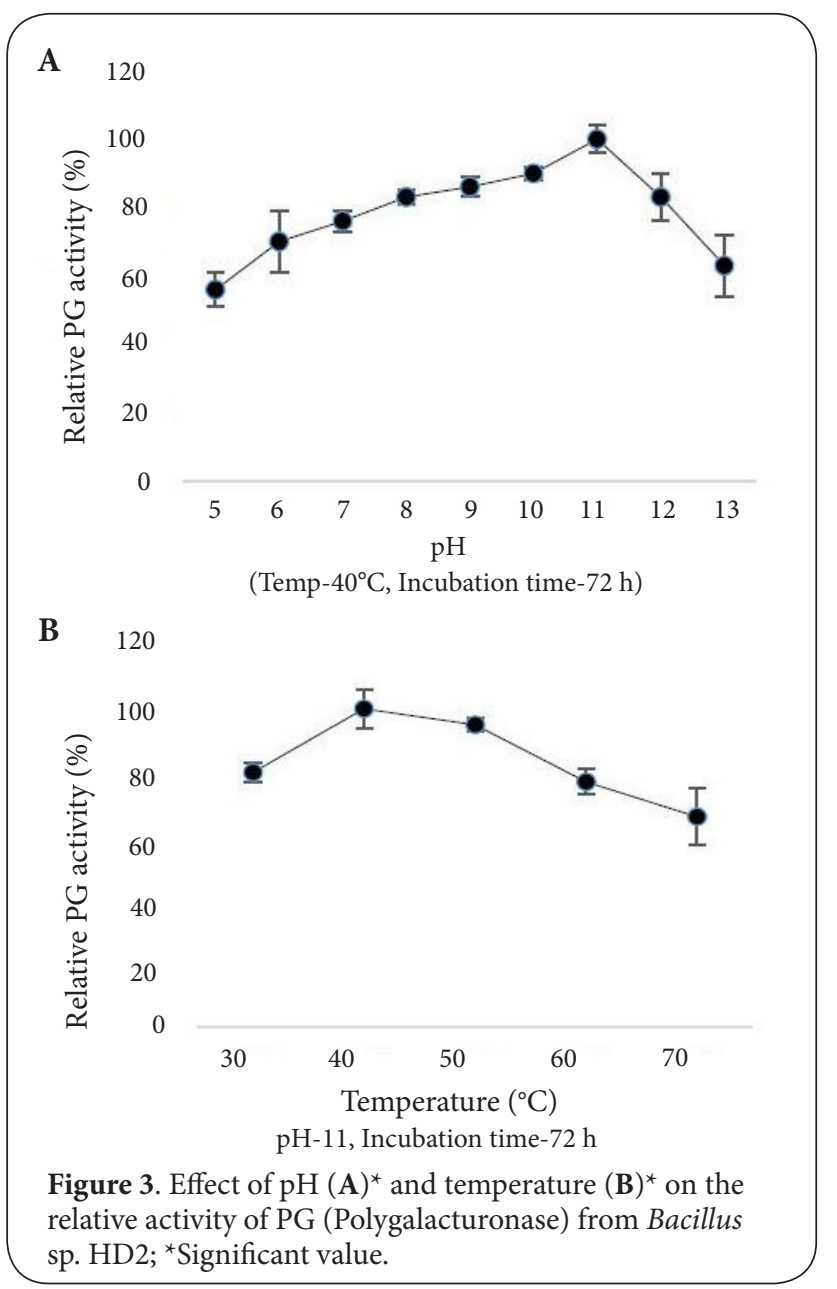




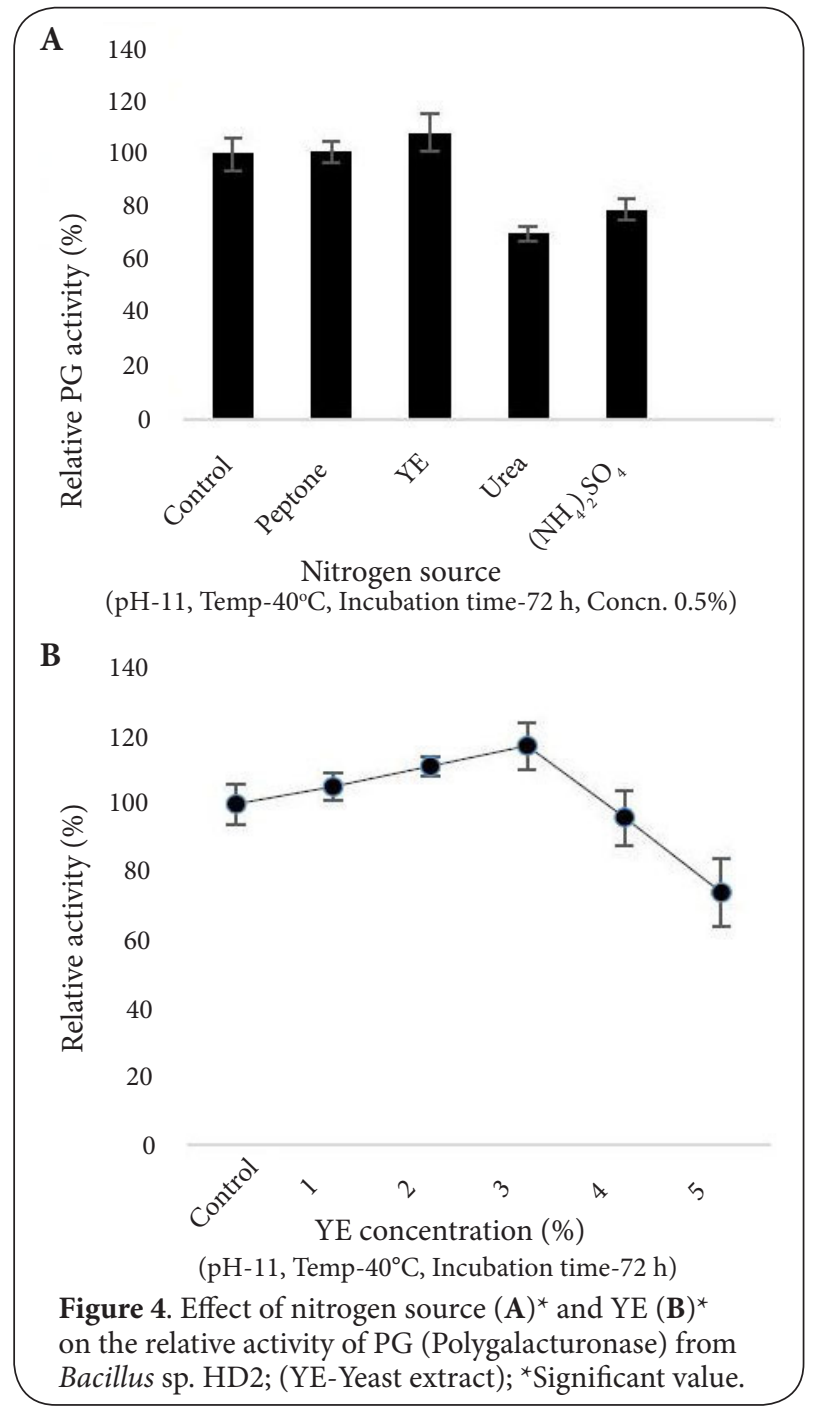

and amino acids which are helpful for bacterial growth and enzyme production. Similar reports were found in Bacillus sp. by Rehman (2012) [29]. Yeast extract is helpful for exo pectinase expression [29,30]. Different concentrations of yeast extract were used for enzyme production and it was found that maximum enzyme production was achieved when $3 \%$ yeast extract was used in the medium. On increasing the concentration of YE over 3\%, the PG relative activity was decreased gradually (Figure 4B).

\section{Effect of metal ions on PG activity}

The activity of polygalacturonase was enhanced by $\mathrm{Ca}^{2+}$ over $\mathrm{Co}^{2+}, \mathrm{Mg}^{2+}, \mathrm{Mn}^{2+}$ and $\mathrm{Zn}^{2+}$. The PG activity by $\mathrm{Ca}^{2+}$ was statistically significant $(p<0.05)$ in comparison to other metal ions. All of these metal ions had no remarkable inhibition effects on PG activity (Figure 5A). While using different concentrations of $\mathrm{Ca}^{2+}$, maximum polygalacturonase was produced at $2 \mathrm{mM}$ of $\mathrm{Ca}^{2+}$. Further, the PG activity was decreased with the higher concentrations of $\mathrm{Ca}^{2+}$ (Figure 5B). Similar

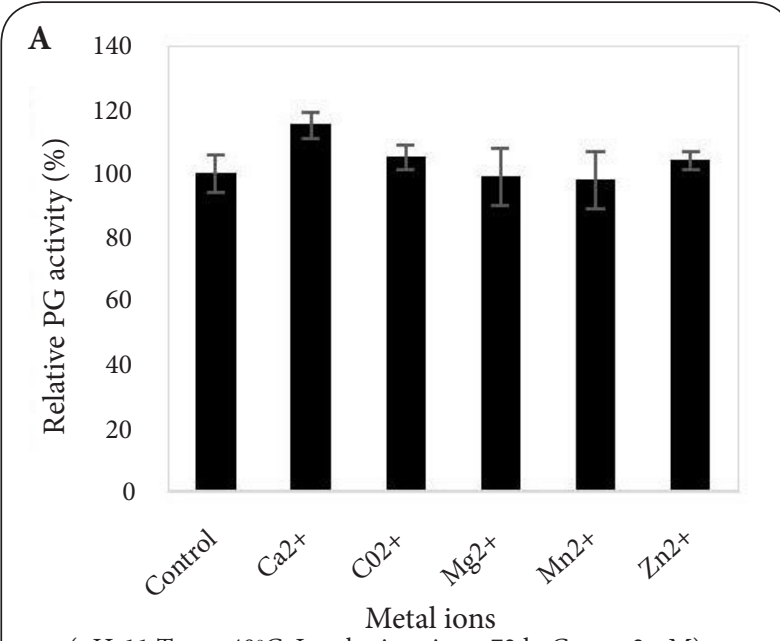

( $\mathrm{pH}-11, \mathrm{Temp}-40^{\circ} \mathrm{C}$, Incubation time- $72 \mathrm{~h}$, Concn. $2 \mathrm{mM}$ )

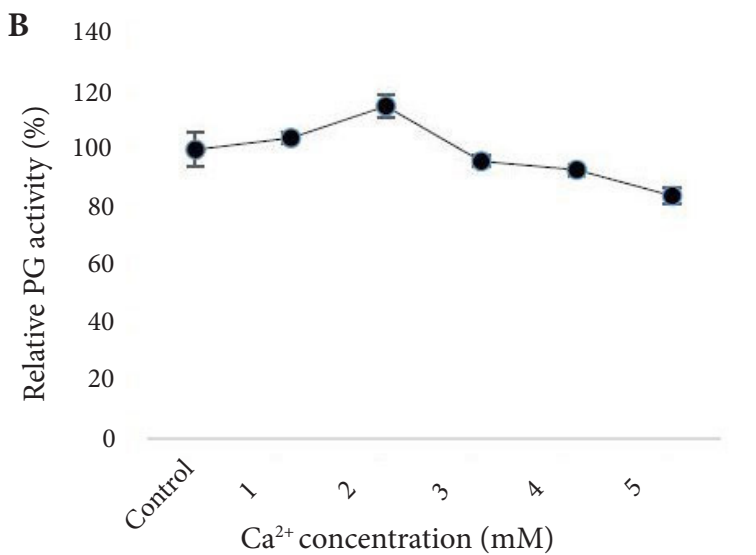

(pH-11,Temp- $40^{\circ} \mathrm{C}$, Incubation time- $72 \mathrm{~h}$, Concn. $2 \mathrm{mM}$ )

Figure 5. Effect of metal ions $(\mathbf{A})^{\star}$ and $\mathrm{Ca}^{2+}(\mathbf{B})^{\star}$ on relative activity of PG (Polygalacturonase) from Bacillus sp. HD2; ${ }^{\star}$ Significant value.

results of polygalacturonase stimulation by $\mathrm{Ca}^{2+}$ were found in Bacillus sp. and Klebsiella sp. Y1 [26,31,32]. The metal ions $\mathrm{Mg}^{2+}, \mathrm{Ca}^{2+}, \mathrm{Zn}^{2+}, \mathrm{Co}^{2+}$ and $\mathrm{Mn}^{2+}$ have been found to stimulate the exopectinase activity by Bacillus GK-8 [33].

\section{Effect of detergents}

The polygalacturonase was found to be significantly tolerant $(p<0.05)$ to surfactant SDS (Figure 6 A) and was reduced by Triton X-100. The stimulation of PG activity by SDS might be due to the increase affinity of active site of the enzyme to the substrate by lowering the surface tension by this detergent. The polygalacturonase activity was found to be most active when 200 mM of SDS was used (Figure 6B). The activity of PG from Bacillus sp. was stimulated by SDS as reported by other researchers [25], while Kobayashi (2001) reported 10\% reduction in polygalacturonase from Bacillus strain by SDS [31]. In other reports, the polygalacturonase from Sporotrichum thermophile was slightly activated by Triton X-100 but the enzyme activity was completely lost by SDS [34]. The tolerance 


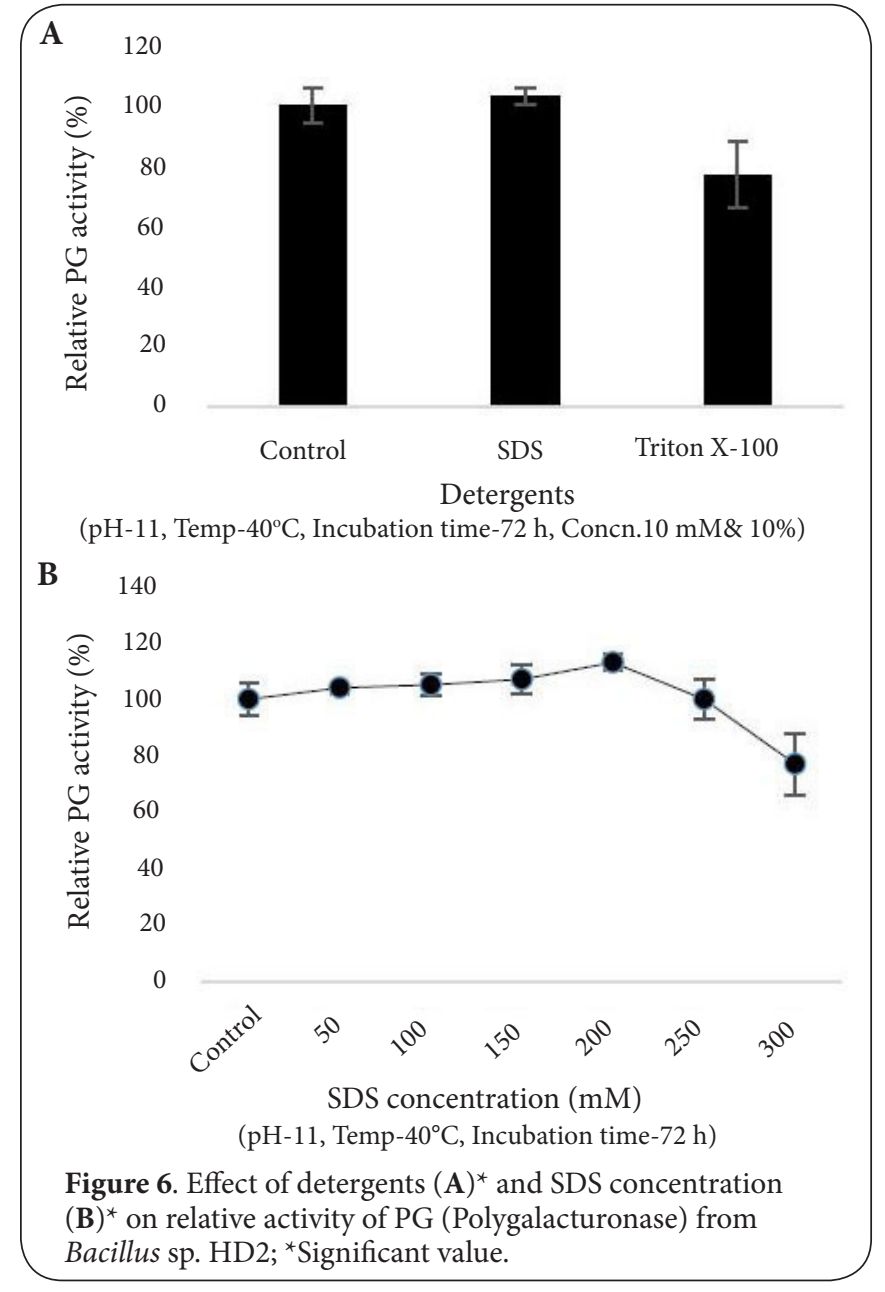

of SDS by PG might be helpful in the industries which require surfactant tolerant reactions in alkaline conditions.

\section{Effect of different biomass in PG production during fermentation}

When the enzyme production profile of Bacillus sp. was studied by using different fruits and vegetables' peels, the enzyme was assayed at $72 \mathrm{~h}$ of incubation. The biomass of apple's peel $(1 \%)$ was found most significant $(p<0.05)$ for the production of polygalacturonase $\left(17.11 \pm 0.46 \mu \mathrm{mol} \mathrm{ml}^{-1} \mathrm{~min}^{-1}\right)$ during fermentation (Figure 7). Apple biomass is an excellent source of polygalacturonase and other pectolytic enzymes $[35,36]$. However, Embaby (2014) reported that orange peel is an effective inducer (carbon source) for alkaline polygalacturonase by Bacillus licheniformis SHG10 [37]. Pectinases could be used to hydrolyse the pectin in pectin rich agro industrial wastes. The bacterial strain in its optimized conditions could be used to increase the polygalacturonase production in industrial scale.

\section{SDS-PAGE analysis}

The SDS-PAGE analysis of crude PG showed different protein bands. Out of which, two clear bands were found with positive

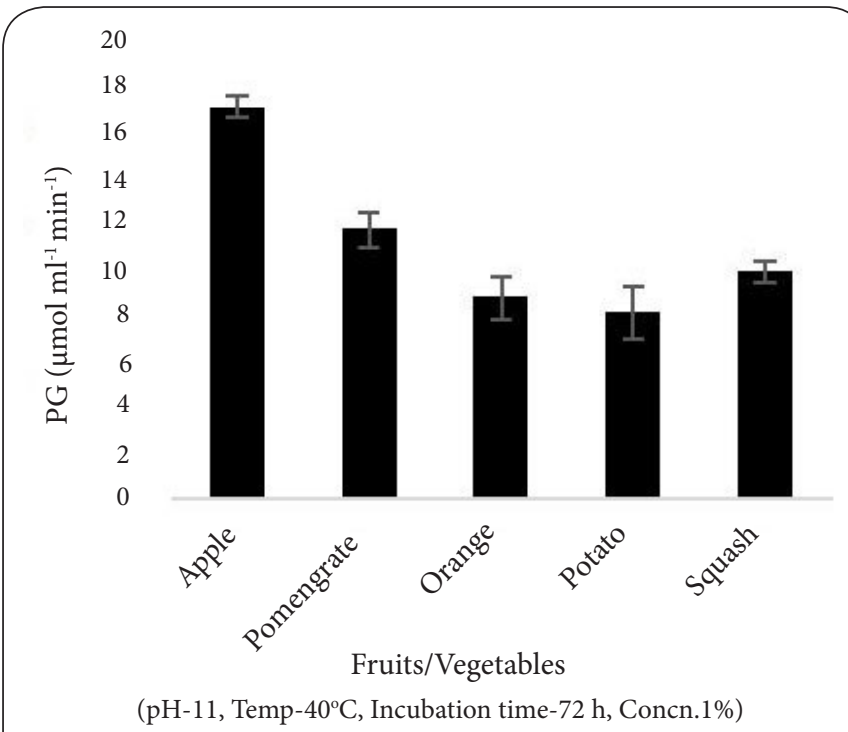

Figure 7. Effect fruits/vegetables' biomass as carbon source on the production of PG (Polygalacturonase)* from Bacillus sp. $\mathrm{HD} 2$; ${ }^{\star}$ Significant value.

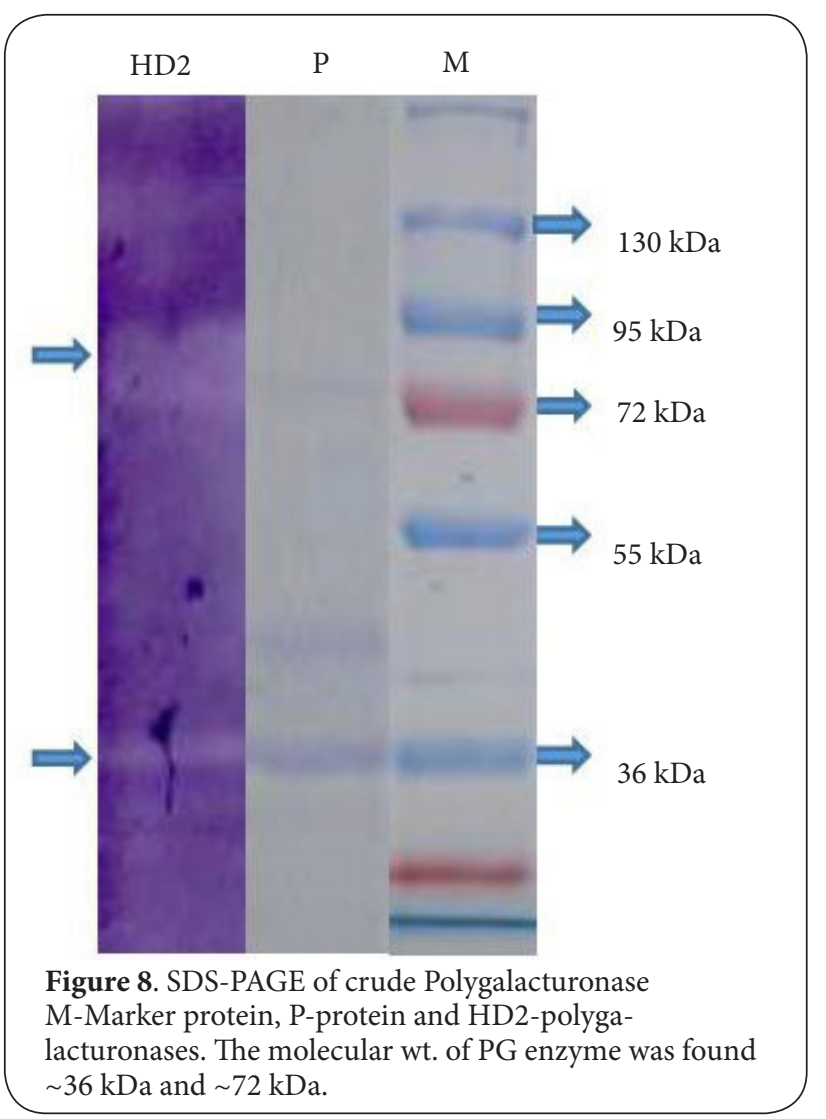

enzyme activity with molecular weights of $\sim 36 \mathrm{kDa}$ and $\sim 72$ $\mathrm{kDa}$ (Figure 8) indicating the possible presence of two main fractions of PGs. These bands could indicate the presence of different proteins or impurities. This study was supported by the findings of several researchers who reported the PGs with 
different molecular weights in different fungal and bacterial strains such as 38 and $61 \mathrm{kDa} ; 38$ and $65 \mathrm{kDa} ; 63$ and $79 \mathrm{kDa}$ from A. niger, A. japonicas and Penicillium frequentans, respectively [38]. Similarly, molecular weights of 36,53 and $68 \mathrm{kDa}$; $66 \mathrm{kDa}$ and $153 \mathrm{kDa}$ were reported from A. sojae, Bacillus sp. MBRL576 and Bacillus licheniformis KIBGE-IB21 respectively [39-41]. Yuan et al., (2014) also reported the molecular weight of PG from Klebsiella sp.Y1 to be $72 \mathrm{kDa}$ [26].

\section{Conclusions}

In this research, a new strain producing polygalacturonase was isolated from the gut of western honey bee (Apis mellifera L.) and identified as Bacillus sp. HD2 after 16S rDNA sequence analysis. Maximum production of polygalacturonase by this strain was achieved at $40^{\circ} \mathrm{C}$ after $72 \mathrm{~h}$ of incubation $(14.31 \pm 0.54$ $\left.\mu \mathrm{mol} \mathrm{ml}{ }^{-1} \mathrm{~min}^{-1}\right)$. A novel, alkaline active and temperature stable polygalacturonase has been produced from this Bacillus $\mathrm{sp}$ HD2 showing molecular weights of $\sim 36 \mathrm{kDa}$ and $\sim 72 \mathrm{kDa}$. The enzyme activity was enhanced by metal ions $\mathrm{Ca}^{2+}$ and detergent SDS. On the basis of these properties, the polygalacturonase from this bacterial strain qualifies for use in the depectinization of pectic wastewaters from industries, as alkalophilic pectinolytic microbes help in the easy removal of pectic material and render it easily decomposed by activated sludge treatment. In addition to these properties, some additional features like enhanced production by yeast extract and apple biomass in the growth medium $(17.11 \pm 0.46 \mu \mathrm{mol}$ $\mathrm{ml}^{-1} \mathrm{~min}^{-1}$ ) and the activity of enzyme in a wide range of $\mathrm{pH}$ indicate the potential use of this organism at commercial level for animal feedstock, degumming of ramie and fruit juice-processing. Further, these results might be helpful to study the enzymatic pectin degradation mechanism in western honey bee (Apis mellifera L.).

\section{Competing interests}

The authors declare that they have no competing interests.

Authors' contributions

\begin{tabular}{|l|c|c|c|c|}
\hline Authors' contributions & YPP & CL & ZS & WQ \\
\hline Research concept and design & $\checkmark$ & -- & -- & $\checkmark$ \\
\hline Collection and/or assembly of data & $\checkmark$ & -- & -- & -- \\
\hline Data analysis and interpretation & $\checkmark$ & $\checkmark$ & -- & $\checkmark$ \\
\hline Writing the article & $\checkmark$ & -- & -- & -- \\
\hline Critical revision of the article & -- & $\checkmark$ & $\checkmark$ & $\checkmark$ \\
\hline Final approval of article & -- & -- & $\checkmark$ & $\checkmark$ \\
\hline Statistical analysis & $\checkmark$ & -- & -- & -- \\
\hline
\end{tabular}

\section{Acknowledgement}

The authors are thankful to NSERC-RDF and Lakehead University for the funding support to this research.

\section{Publication history}

Editors: Antonio Pedro Fonseca, University of Porto, Portugal. Devendra Dusane, McGill University, Canada.

Received: 12-Mar-2015 Final Revised: 28-May-2015

Accepted: 30-May-2015 Published: 06-Jun-2015

\section{References}

1. Aouali N, Laporte $\mathrm{P}$ and Clement $\mathrm{C}$. Pectin secretion and distribution in the anther during pollen development in Lilium. Planta. 2001; 213:71-9. | Article | PubMed

2. Klungness LM and Peng YS. A histochemical study of pollen digestion in the alimentary canal of honeybees (Apis mellifera L.). J Insect Physiol. 1984; 30:511-521. | Article

3. Engel $P$, Martinson VG and Moran NA. Functional diversity within the simple gut microbiota of the honey bee. Proc Natl Acad Sci U S A. 2012; 109:11002-7. | Article | PubMed Abstract | PubMed Full Text

4. Barker RJ. Some carbohydrates found in pollen and pollen substitutes are toxic to honey bees. J Nutr. 1977; 107:1859-62. | Article | PubMed

5. Contreras Esquivel JC and Voget CE. Purification and partial characterization of an acidic polygalacturonase from Aspergillus kawachii. J Biotechnol. 2004; 110:21-8. I Article I PubMed

6. Souza JV, Silva ES, Maia ML and Teixeira MF. Screening of fungal strains for pectinolytic activity: endopolygalacturonase production by Peacilomyces clavisporus 2A. UMIDA. 1. Process Biochem. 2003; 39:455458. | Article

7. Rombouts FM and Pilnik W. Pectinases and other cell-wall degrading enzymes of industrial importance. Symbiosis.1986; 2:79-90.

8. Tanabe H, Yoshihara K, Tamura K, Kobayashi Y, Akamatsu I, Niyomwan $\mathrm{N}$ and Footrakul P. Pretreatment of pectic wastewater from orange canning process by an alkalophilic Bacillus sp. J ferment technol. 1987; 65:243-246. | Article

9. Baracat MC, Valentim C, Muchovej JJ and Silva DO. Selection of pectinolytic fungi for degumming of natural fibers. Biotechnol Lett. 1989; 11:899-902. | Article

10. Kashyap DR, Vohra PK, Chopra S and Tewari R. Applications of pectinases in the commercial sector: a review. Bioresour Technol. 2001; 77:215-27. | Article | PubMed

11. Salazar $L$ and Jayasinghe $U$. Fundamentals of purification of plant viruses. Techniques in plant virology. CIP, Training manual, JO, Virus Purification, International Potato Centre, Peru. 1999; 1-10.

12. Reid II and Ricard M. Pectinase in papermaking: solving retention problems in mechanical pulps bleached with hydrogen peroxide. Enzyme Microb Technol. 2000; 26:115-123. | Article I PubMed

13. Birgisson H, Delgado O, Garcia Arroyo L, Hatti-Kaul R and Mattiasson B. Cold-adapted yeasts as producers of cold-active polygalacturonases. Extremophiles. 2003; 7:185-93. | Article | PubMed

14. Holt JG, Krieg NR, Sneath PH, Staley JT and Williams ST. Bergey's manual of determinative bacteriology. Baltimore: Williams and Wilkins. 1994; 75:121.

15. Salomao TMF, Amorim ACR, Alves VMC, Coelho JLC, Silva DO and Araujo E. Isolation of pectinase hyperproducing mutants of Penicillium expansum. Rev Microbiol. 1996; 27:15-18.

16. Miller GL. Use of DNS reagent for the measurement of reducing sugar. Anal Chem. 1959; 31:426-428. I Pdf

17. Bradford MM. A rapid and sensitive method for the quantitation of microgram quantities of protein utilizing the principle of protein-dye binding. Anal Biochem. 1976; 72:248-54. | Article I PubMed

18. Laemmli UK. Cleavage of structural proteins during the assembly of the head of bacteriophage T4. Nature. 1970; 227:680-5. | PubMed

19. Soriano M, Diaz P and Pastor Fl. Pectinolytic systems of two aerobic sporogenous bacterial strains with high activity on pectin. Curr Microbiol. 2005; 50:114-8. I Article | PubMed

20. Jayani RS, Shukla SK and Gupta R. Screening of Bacterial Strains for Polygalacturonase Activity: Its Production by Bacillus sphaericus (MTCC 7542). Enzyme Res. 2010; 2010:306785. | Article | PubMed Abstract | PubMed Full Text

21. Anam T and Zakia L. Isolation and biochemical characterization of bacterial isolates producing different levels of polygalacturonases from various sources. Afr J Microbiol Res. 2012; 6:7259-7264. | Pdf

22. Dave BA and Vaughn RH. Purification and properties of an 
Paudel et al. Microbiology Discovery 2015,

polygalacturonic acid trans-eliminase produced by Bacillus pumilus. J Bacteriol. 1971; 108:166-74. | Article | PubMed Abstract | PubMed Full $\underline{\text { Text }}$

23. Nagel CW and Vaughn RH. The degradation of oligogalacturonides by the polygalacturonase of Bacillus polymyxa. Arch Biochem Biophys. 1961; 94:328-32. | Article | PubMed

24. Karbassi A and Vaughn RH. Purification and properties of polygalacturonic acid trans-eliminase from Bacillus stearothermophilus. Can J Microbiol. 1980; 26:377-84. | Article | PubMed

25. Kapoor M, Khalil Beg Q, Bhushan B, Dadhich KS and Hoondal GS. Production and partial purification and characterization of a thermoalkali stable polygalacturonase from Bacillus sp. MG-cp-2. Process Biochem. 2000; 36:467-473. | Article

26. Yuan $P$, Meng $K$, Wang $Y$, Luo $H$, Shi $P$, Huang $H$, Bai $Y$, Yang $P$ and Yao $B$. A protease-resistant exo-polygalacturonase from Klebsiella sp. Y1 with good activity and stability over a wide $\mathrm{pH}$ range in the digestive tract. Bioresour Technol. 2012; 123:171-6. | Article | PubMed

27. Bhatti HN, Asgher M, Abbas A, Nawaz R and Sheikh MA. Studies on kinetics and thermostability of a novel acid invertase from Fusarium solani. J Agric Food Chem. 2006; 54:4617-23. | Article | PubMed

28. Kashyap DR, Chandra S, Kaul A and Tewari R. Production, purification and characterization of pectinase from a Bacillus sp. DT7. World J Microbiol Biotechnol. 2000; 16:277-282. | Article

29. Rehman HU, Qader SA and Aman A. Polygalacturonase: production of pectin depolymerising enzyme from Bacillus licheniformis KIBGE IB-21. Carbohydr Polym. 2012; 90:387-91. | Article | PubMed

30. Aguilar G, Trejo BA, Garcia JM and Huitron C. Influence of pH on endoand exo-pectinase production by Aspergillus sp. CH-Y-1043. Can J Microbiol. 1991; 37:912-917. | Article

31. Kobayashi T, Higaki N, Suzumatsu A, Sawada K, Hagihara H, Kawai S and Ito $S$. Purification and properties of a high-molecular-weight, alkaline exopolygalacturonase from a strain of Bacillus. Enzyme Microb Technol. 2001; 29:70-75. | Article | PubMed

32. Raj Kashyap D, Kumar Soni S and Tewari R. Enhanced production of pectinase by Bacillus sp. DT7 using solid state fermentation. Bioresour Technol. 2003; 88:251-4. | Article | PubMed

33. Dosanjh NS and Hoondal GS. Production of constitutive, thermostable, hyper active exo-pectinase from Bacillus GK-8. Biotechnol Lett. 1996; 18:1435-1438. | Article

34. Kaur G, Kumar S and Satyanarayana T. Production, characterization and application of a thermostable polygalacturonase of a thermophilic mould Sporotrichum thermophile Apinis. Bioresour Technol. 2004; 94:239-43. | Article | PubMed

35. Berovic $\mathrm{M}$ and Ostroversnik H. Production of Aspergillus niger pectolytic enzymes by solid state bioprocessing of apple pomace. J Biotechnol. 1997; 53:47-53. | Article | PubMed

36. Hours RA, Voget CE and Ertola RJ. Apple pomace as raw material for pectinases production in solid state culture. Biol Waste. 1988; 23:221228. | Article

37. Embaby AM, Masoud AA, Marey HS, Shaban NZ and Ghonaim TM. Raw agro-industrial orange peel waste as a low cost effective inducer for alkaline polygalacturonase production from Bacillus licheniformis SHG10. Springerplus. 2014; 3:327. | Article | PubMed Abstract | PubMed Full Text

38. Jayani RS, Saxena S and Gupta R. Microbial pectinolytic enzymes: a review. Process Biochem. 2005; 40:2931-2944. | Article

39. Tari C, Dogan N and Gogus N. Biochemical and thermal characterization of crude exo-polygalacturonase produced by Aspergillus sojae. Food Chem. 2008; 111:824-829. | Article

40. Rehman HU, Aman A, Nawaz MA and Qader SAU. Characterization of pectin degrading polygalacturonase produced by Bacillus licheniformis KIBGE-IB21. Food hydrocolloid. 2015; 43:819-824. | Article

41. Bhardwaj V and Garg N. Production, Purification of Pectinase from Bacillus sp. MBRL576 Isolate and its Application in Extraction of Juice. Int J Sci Res. 2014; 3:648-652. | Pdf
Citation:

Paudel YP, Lin C, Shen Z and Qin W. Characterization of pectin depolymerising exo polygalacturonase by Bacillus sp. HD2 isolated from the gut of Apis mellifera L. Microbiol Discov. 2015; 3:2.

http://dx.doi.org/10.7243/2052-6180-3-2 